【論 文】

UDC : 697.13

\title{
水分蒸発による冷却効果を利用した外断熱壁体の 高性能化に関する研究
}

\section{1.はじめに}

建物における夏季の防暑対策として，外壁外表面での 蒸発冷却を利用した貫流熱取得低減方法が考えられ，現 在, 木村”，石川 ${ }^{21}$, 松本 ${ }^{31}$ らによって屋根散水や吸水性 屋根面を対象とした研究が進められている。

筆者らも，外断熱壁体の夏季における熱的性能を改善 するため，外断熱構法とした外壁の断熱材を夏季だけ飽 水状態に保つ「外壁蒸発冷却方式」を提案し，すでに， 二棟の試験家屋を用いた屋外比較実験とシミュレーショ ンによりその有効性を確認している4),5)。しかし, 試験 家屋の蒸発部位はほとんど断熱材のみからなる壁体で構 成されていたため,その室内側軀体熱容量は小さく, 本研 究で対象とする外断熱とは異なる仕様であった。本方式 の実用化に際しても，冬季における断熱材の気乾状態維 持方法や断熱材の選定とその劣化に関する問題などいく つかの課題が残されていた。また, 夏季蒸暑地域に属し ている西日本では, 蒸発冷却単独の効果には限界があり, 日射遮へいや大気放射冷却など他の建築的手法と併用し て外壁での熱の流れを上手にコントロールすることが大 切である。

以上のような観点から，本論文では，蒸発冷却の利用 による外断熱壁体の夏季熱性能改善を目的として, 以下 の実験・解析を行った。

（1）試験家屋の壁体熱容量を増加して屋外比較実験 を行い, 蒸発冷却方式の防暑効果について検討するが, 冬季の断熱性能を確保するため断熱材の表面処理につい ても考慮する。

（2）外側断熱材を飽水化し外被パネルで蒸発面の日 射を遮へいする二重外被方式が試験家屋の自然室温変動 に及ぼす影響を，屋外比較実験により明らかにする。

*11 九州大学 教授. 工博

*2) 九州大学 助教授. 工博

*3) 九州大学 助手. 工博

*4) 九州大学 大学院生・工修 (昭和 60 年 5 月 7 日原稿受理)

$\begin{array}{lllll}\text { 正会員 } & \text { 浦 } & \text { 野 } & \text { 良 } & \text { 美*1) } \\ \text { 正会貝 } & \text { 渡 } & \text { 辺 } & \text { 俊 } & \text { 行*2) } \\ \text { 正会員 } & \text { 林 } & & \text { 徹 } & \text { 夫*3) }^{* 3} \\ \text { 正会員 } & \text { 龍 } & & \text { 有 } & \text { 二 }^{* 4)}\end{array}$

（3）試験家屋を対象としたシミュレーションにより 蒸発冷却方式と二重外被方式の防暑効果について検討す る。

なお,断熱材の選定およびその劣化の問題については, 現在, 模擬太陽装置を用いた屋内実験 ${ }^{6}$ により検討中で あるが，その報告は次の機会に譲ることにする。

\section{2. 蒸発冷却方式}

\section{1 実験内容}

文献 4）で使用した試験家屋の壁体熱容量を増加して 一棟を外断熱構法, もう一棟を内断熱構法に改造し, 外 側の断熱材を飽水化した場合の防暑効果について二棟の 比較実験により検討する。使用した断熱材は, 軽量石綿 珪酸カルシウム板 (以下, 軽力板と略称する), 白色通 気防水シートで覆った軽力板, および白色撥水剂を塗布 した発泡モルタルである。このように表面処理をした断熱 材を用いたのは，冬季は外側断熱材を気乾状態に維持し て外断熱効果を確保し, さらに夏季は断熱材の飽水化に よる外表面日射反射率の低下を防ぐためである。

\section{2 試験家屋概要}

二棟の試験家屋全景を写真一 1 に示すが，一連の比較 実験で各手法の検討を行う際，二棟の試験家屋のうち， その手法を施した家屋を $\mathrm{A}$ 棟, 比較の基準となる家屋を $\mathrm{B}$ 棟と仮称する。

文献 4) で用いた二棟の試験家屋の東・西壁と床にモ ルタル・レンガを付設して壁体熱容量の増加を図った。 図一1の東・西壁(3), (6)の構成は，A 棟では室内側から

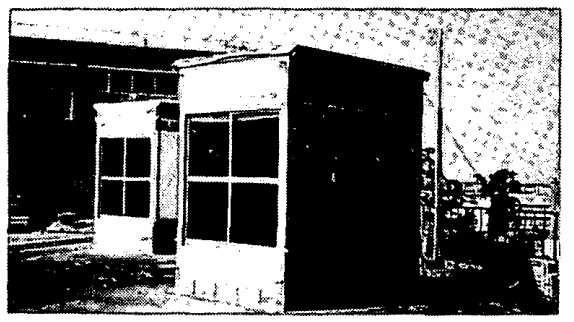

写真一1 試験家屋全景（実験 I） 


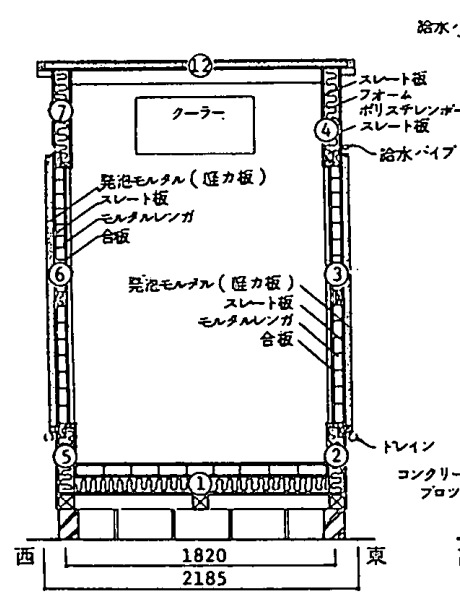

図一1試験家屋東西断面図

(実験 $\mathrm{I}$, 単位 $\mathrm{mm}$ )

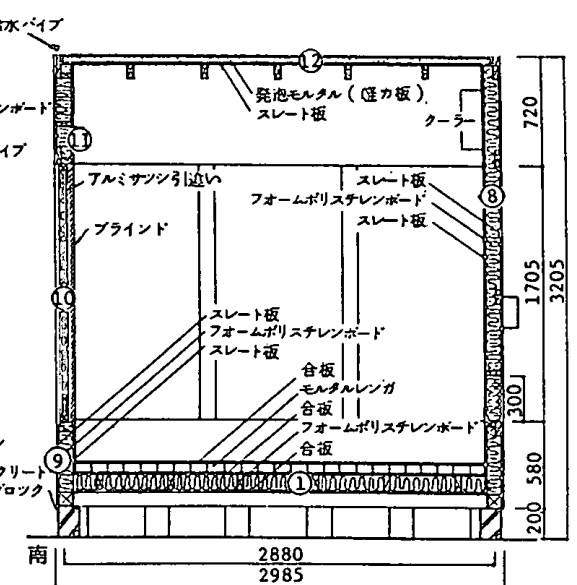

图一2 試験家屋南北断面図

(実験 I, 単位 $\mathrm{mm}$ )

表一1 二棟の試験家屋による屋外比較実験内容

\begin{tabular}{|c|c|c|c|c|}
\hline 实 㷿 琴 & \multirow[t]{2}{*}{ 柃 璟 幊 目 } & \multicolumn{2}{|c|}{ 实 路 答件 } & 说 \\
\hline (英鹳月日) & & A & B 场 & \\
\hline $\begin{array}{c}I-1 \\
(6 / 29,30)\end{array}$ & 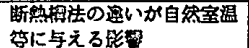 & 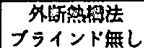 & $\begin{array}{l}\text { 内断億擢法 } \\
\text { フライント無し }\end{array}$ & 绁急材として的力板を使用 \\
\hline$\left(\begin{array}{c}1-2 \\
(7 / 7 \sim 7 / 9)\end{array}\right.$ & 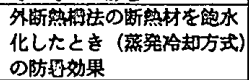 & $\begin{array}{l}\text { 繁聟冾却方式 } \\
\text { ブラインド無し }\end{array}$ & $\begin{array}{l}\text { 内断㠇舫法 } \\
\text { フライント無し }\end{array}$ & 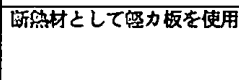 \\
\hline $\begin{array}{c}I-3 \\
(7 / 23 \sim 7 / 25)\end{array}$ & 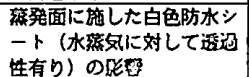 & 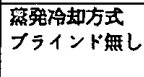 & $\begin{array}{l}\text { 内断慗挴法 } \\
\text { フライント無し }\end{array}$ & 岓的材として婜力板を便用 \\
\hline $\begin{array}{c}I-4 \\
(8 / 2 I \sim 8 / 23)\end{array}$ & 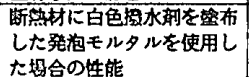 & 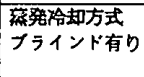 & $\begin{array}{l}\text { 内断愁抱法 } \\
\text { ブラインド有り }\end{array}$ & 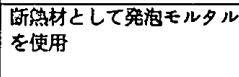 \\
\hline $\begin{array}{c}I-5 \\
(9 / 8)\end{array}$ & 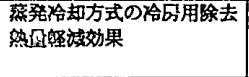 & 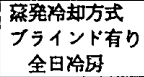 & 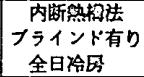 & $\begin{array}{l}\text { 断㥎材として発泡モルタル } \\
\text { を使用 }\end{array}$ \\
\hline
\end{tabular}

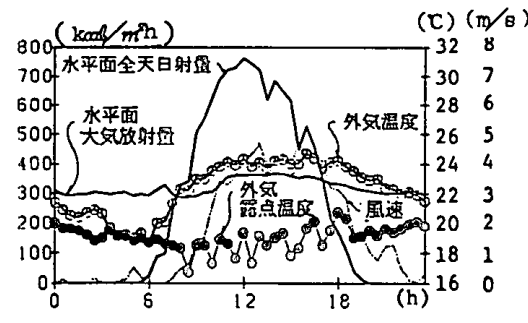

图一5 実験 I - 2 の外界気象要素 (7月9日)

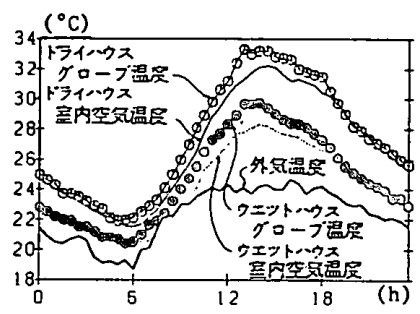

国一6 実験 I -2 の室内空気温度および グローブ温度(7月9日)

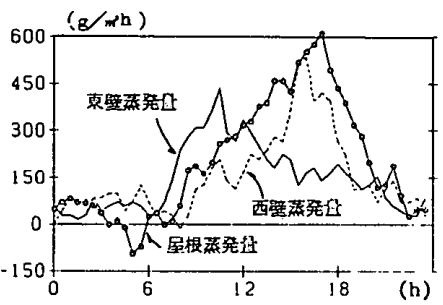

图一7 実験 I -2 の水分蒸発量 (7月9日)

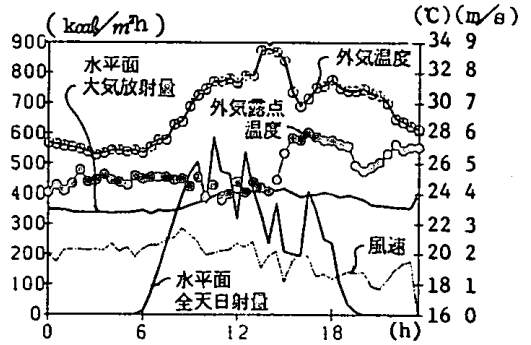

図一8 実験 I -3 の外界気象要素 (7月 25 日)

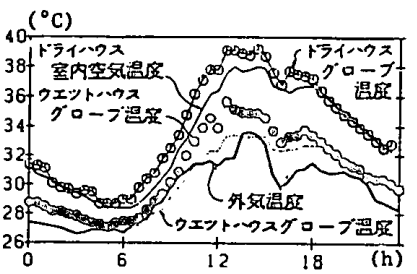

图一9 実験 I -3 の室内空気温度および グローブ温度（7月25日）

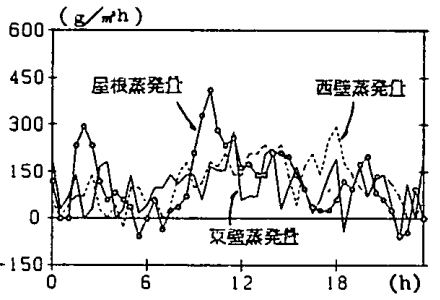

図一10 奏験 I -3 の水分蒸発里 (7月25日)
順に合板 $6 \mathrm{~mm}$ (灰色ペイント仕上げ）, モルタル・レンガ $60 \mathrm{~mm}$ ，スレート板 3 $\mathrm{mm}$ ，断熱材とし，B棟では室内側から合 板 $6 \mathrm{~mm}$ (灰色ペイント仕上げ), 断熱材, モルタル・レンガ $60 \mathrm{~mm}$ ，スレート板 3 $\mathrm{mm}$ とした。すなわち，壁体(3)，(6)を A 棟 では外断熱構法, B 梖では内断熱構法とし

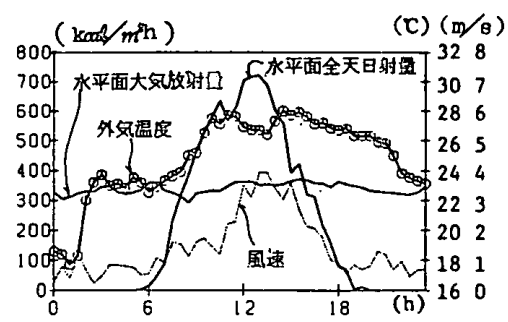

图一3 実験 I - 1 の外界気象要素

(6月 30 日)

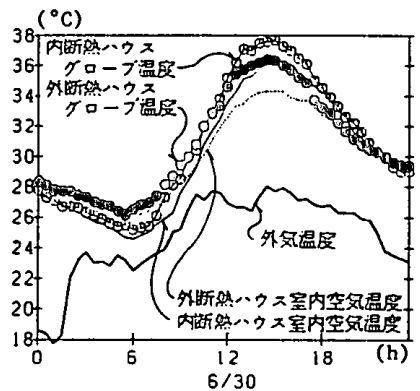

図一4 実験 I-1 の室内空気温度および グローブ温度 (6月30日)

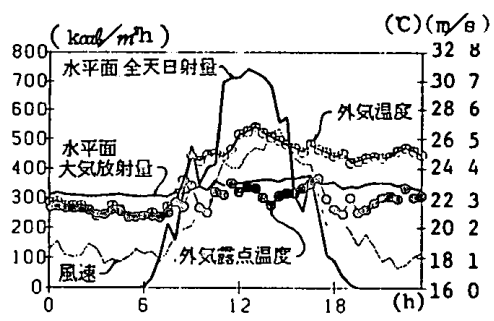

图-11 実験 I -4 の外界気象要素 (8月 22 日)

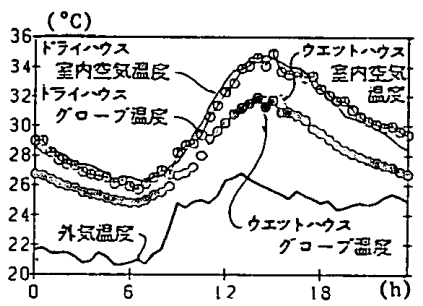

図一12 実験 I -4 の室内空気温度および グローブ温度（8月22日）

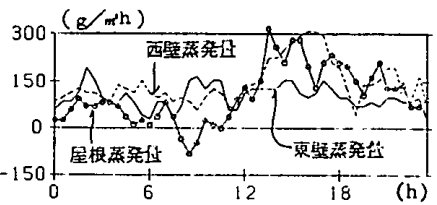

図一13 実験 I -4 の水分蒸発哩 (8月 22 日) 
ており，それ以外は $\mathrm{A} \cdot \mathrm{B}$ 二棟とも同一仕様である。 ただし，モルタル・レンガの内側に断熱材を設置した B 棟は，外側に断熱材を設置したA 棟より室容積が約 $4 \%$ 小さくなる。

なお，A棟には，壁体(3)，(6)よび屋根の外側断熱材 を飽水状態に保ち，各飽水層からの蒸発量を測定できる 装置を設置している4)。

\section{3 実験結果と考察}

1984 年夏季に行った一連の屋外比較奏験のうち, 主 なものについてその内容を表一1に示す。

実験 I-1 では，A棟の外側断熱材を気乾状態に保ち, 断熱構法の違いが自然室温に与える影響を検討した。断 熱材には $50 \mathrm{~mm}$ 厚の軽力板を使用している。実験結果 を図一3，4に示すが，外断熱構法とした A 棟の室内空 気温度およびグローブ温度は内断熱構法とした B 棟に比 べ最高值で約 $2^{\circ} \mathrm{C}$ 低く, 最低值で約 $2^{\circ} \mathrm{C}$ 高い。

図一5〜 7 に実験 I -2 の, 図一8〜10には実験 I -3の, そして図一11〜13には実験 I -4 の結果を示す。これら $3 つ$ 実験はいずれも $\mathrm{A}$ 棟の外側断熱材を飽水状態に 保った場合，つまり A 棟を蒸発冷却方式，B棟を内断熱 方法とした場合である。ただし，実験 I -2では壁体(3), (6)，(12)の断熱材に軽力板を使用しており，実験 I -3で は白色通気防水シートで覆った軽力板を，実験 I -4で はフッ素系白色撥水剂を塗布した $60 \mathrm{~mm}$ 厚の発泡モル タルを使用した。白色通気防水シート（シート孔径 0.6 $\mu \mathrm{m}$, 有孔率 $80 \%$ ）は水蒸気に対して透過性があるが, 雨水に対する透過性はない。したがって，断熱材に給水 しない冬季には断熱材を気乾状態に保つことができる。 また，白色撥水剤の塗布によっても断熱材内部への雨水 の侵入を抑えることが可能である。断熱材料の熱的特性 値を表一 2 に示すが，その測定法おょびその他の壁体構 成材料の熱的特性值は文献 4）亡同様である。なお，表 -2 に示している蒸発比 $f$ は, 飽水化した各断熱材
(300 mm × $300 \mathrm{~mm} \times$ 厚さ $40 \mathrm{~mm})$ を屋外に暴露して 行った蒸発量測定結果に基づき算出した值である。本来, 蒸発比は完全濡れ面における蒸発量 $W_{0}$ と各試料からの 実際の蒸発量 $W$ との比 $W / W_{0}$ として定義されるが，本 論文では飽水状態にある軽力板からの蒸発量 $W_{k}$ が $W_{0}$ に等しいとみなし， $f=W / W_{k}$ で表す。このように, 軽 力板表面を白色通気防水シートで覆った場合や発泡モル タル表面に白色撥水剤を塗布した場合の蒸発量は, 表面 処理のない軽力板に比べて $66 \%$ に減少する。このこと は図一7，10，13に示す蒸発量測定值からも明らかであ る。しかし，白色通気防水シートや白色撥水剤塗布面の 日射吸収率は飽水化によっても值が増大せず, 飽水状態 の軽力板日射吸収率に比べてそれぞれ $65 \%$ ，58\%であ るため, 実験 $\mathrm{I}-2,3,4$ いずれも蒸発冷却方式 $\mathrm{A}$ 棟の 室内空気温度は内断熱方式 $\mathrm{B}$ 棟のそれよりより昼間 3 $4^{\circ} \mathrm{C}$, 夜間 $1.5 \sim 2^{\circ} \mathrm{C}$ 低い。

図一14，15には夷験 I -1 と実験 I -3 におけるA棟の 内表面流入熱流（外表面から内表面へ向かう方向を正亡 する）を示すが，これは壁体外表面温度と内表面温度の 実測値を用いて計算したものである。断熱材を気乾状態 に保ち外断熱方式とした実験 I -1のA 棟東・西壁では, 昼間に内表面から壁体内部へ, 夜間には逆に壁体内部か ら内表面に熱が流れる傾向がある。これは昼間の空面透 過日射熱取得の一部がモルタル・レンガ内に蓄熱され， 夜間はその熱が室内に放熱されることを示している。ま た, 室内側に熱容量を持たない屋根では内表面熱流の変 動幅は比較的小さい。一方, 蒸発冷却方式とした実験 I -3 のA 棟東・西壁では, 昼夜を問わず内表面から壁体 内部へと熱が流れる。これは飽水化により断熱材の熱抵 抗が低下し, モルタル・レンガに蓄えられた熱が夜間室 外へ流出するためである。

図一16，17 には全日冷房（設定温度域 $24^{\circ} \mathrm{C} \sim 28^{\circ} \mathrm{C}$ ) した実験 I-5の結果を示す。A棟と B 棟の冷房用消費

表-2 試験家屋壁体材料の熱的特性值（その 1)

\begin{tabular}{|c|c|c|c|c|}
\hline 部 & 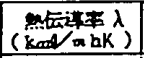 & 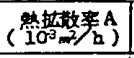 & $\begin{array}{c}\text { 日射㖟収案 } \\
a\end{array}$ & 丞無比 \\
\hline 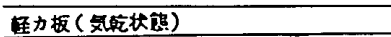 & 0.066 & 0.33 & 0.31 & - \\
\hline 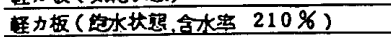 & 0.51 & 0.96 & 0.52 & 1.00 \\
\hline 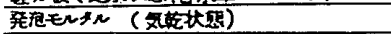 & 0.090 & 0.89 & 0.29 & - \\
\hline 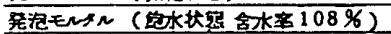 & 0.30 & 0.68 & 0.30 & 0.66 \\
\hline 白色通気防ホシー1 & - & - & 0.34 & $0.66^{1}, 0.83^{4}$ \\
\hline
\end{tabular}

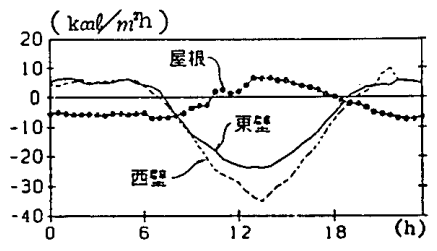

図一14 実験 I - 1 の A 棟の内表面熱流 (6月 30 日)

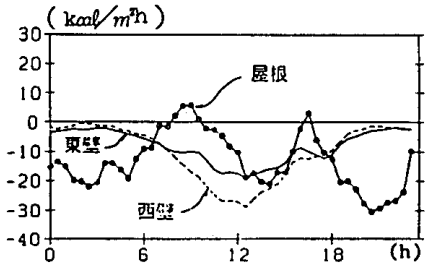

図-15 夷験 I -3 のA棟の内表面熱流 (7月 25 日)

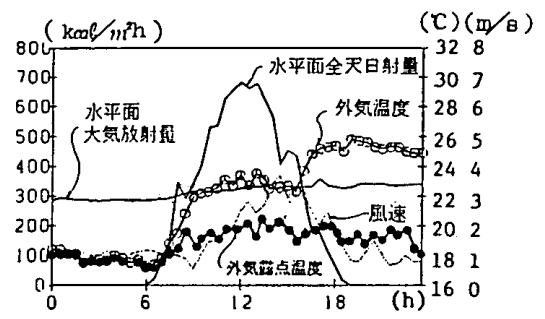

图一16 実験 I -5 の外気象要素 (9月 8 日)

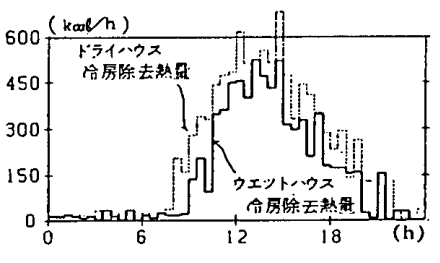

図-17 実験 I -5 の冷房除去熱量

(9月 8 日) 
電力日積算値はそれぞれ $2064 \mathrm{Wh} ， 2707 \mathrm{Wh}$ (除去熱 量日積算值に換算するとそれぞれ $3715 \mathrm{kcal}, 4740 \mathrm{kcal}$ ) となり，蒸発冷却方式としたA 槙の冷房用消費電力は内 断熱方式のB棟に比べ $24 \%$ 減少した。

\section{3. 二重外被方式}

\section{1 実験内容}

2 節で示したように蒸発冷却方式は，夏季に外壁外表 面からの蒸発潜熱を利用するだけでなく，断熱材の飽水 化による壁体熱抵抗の低下を伴う。したがって，外壁外 表面を何らかの手法で積極的に冷却することにより，従 来の構法では得ることのできなかった放熱効果が期待で きる。本節では，夏季に外側断熱材を飽水化し外被パネ ルで蒸発面の日射を遮へいする二重外被方式が試験家屋 の自然室温変動に及ぼす影響について, 改造試験家屋を 用いた屋外比較実験により検討する。なお，屋根面につ いては夜間の放射冷却を利用するため可動外被とした。

\section{2 改造試験家屋概要}

写真一 2 , 図一 18 に示すように, $\mathrm{A}$ 棟の東・西壁と A・ $\mathrm{B}$ 二棟の北壁を室内側から順に合板 $6 \mathrm{~mm}$ (灰色ぺイン ト仕上げ)，モルタル・レンガ $60 \mathrm{~mm}$, スレート板 $3 \mathrm{~mm}$, 断熱材となる甘様に改造した。つまり，二棟とも屋根と 床を除く壁体の大部分を同様の外断熱構法としている。 また，二棟とも窓面の入射日射を遮るため空面上部にひ さしをつけ，屋根も日射受熱量を減らすため 10 度北流 れに変更した。

本実験では，屋根および東・西・北壁の断熱材にはす ベて $50 \mathrm{~mm}$ 厚の珪酸カルシウム・ゾノトライト板（以下， ゾノトライト板と略記する) を使用した。ゾノトライト 板の熱的特性值を表一 3 に示すが，実験 I で使用した軽 力板や発泡モルタルより気乾状態の熱伝導率が小さく保 水性能も高い。

東・西壁および北壁の日射を遮へいする場合には，原 則として白色カラー鉄板（0.45 mm 厚）を外被パネル こして使用し，壁面から $35 \mathrm{~mm}$ 離して設置した。屋根 面については夜間の大気放射冷却を利用するため，0.7

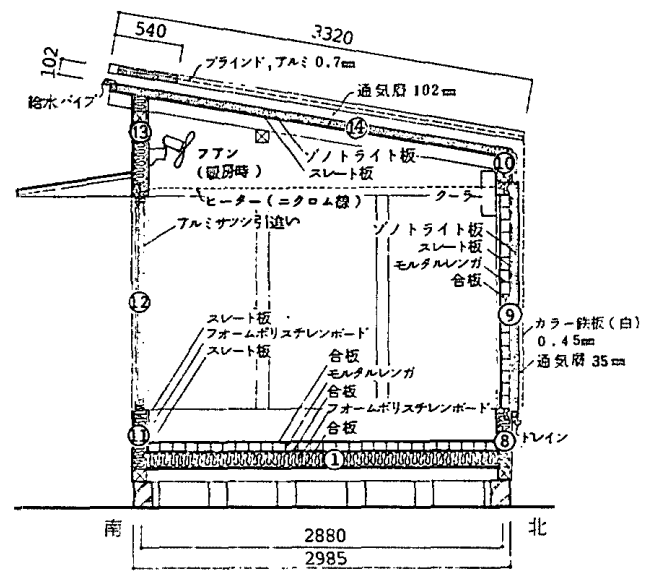

图一18 試験家屋南北断面図 (実験 II，単位 $\mathrm{mm}$ )

$\mathrm{mm}$ 厚のアルミ製可動ブラインド（以下，屋根ブライン ドと略記する) を屋根面から $102 \mathrm{~mm}$ 離して設置した。 この屋根ブラインドは手動ハンドルによって開閉でき， 写真一 3 に示すように全開時で屋根面の $84 \%$ が天空に 開放される。外被パネルの仕様としては，東·西壁および 北壁の外被（以下，垂直壁外被パネルと略記する）と屋 根ブラインドを分離した「標準仕様」，および一体化し た「一体化仕様」を考える。図一19に示しているように， 一体化仕様の場合, 屋根ブラインドを全閉すると通気層 への空気の流入および流出は, 東・西・北壁下部と屋根 南側頂部に限定される。標準仕様の場合は, 東・西・北 壁の上下と屋根四周で空気の流入, 流出がある。両仕様 とも冬季にはこれらの外被パネルにより断熱材を雨露か ら防護して気乾状態に保ちうる。

また，A・B 二棟とも屋根，東・西・北壁の外側断熱 材を飽水状態に保つことができるよう実験 I と同様の装 置を設置している。なお，一連の実験では，A棟の屋根 断熱材表面に選択放射板としてシリコン系塗料仕上げ有 孔アルミ板（以下，選択放射板と略記する）を設置し， 選択放射の効果も検討する。

\section{3 実験結果と考察}

二掼の熱的同一性能を確認したのち，表一4に示す条 件のもとで屋外比較実験を行った。表一 5 には各実験番 号に対応する外気温度，A棟およびB棟室内空気温度の

\section{䝮一3 試験家屋壁体材料の熱的特性値（その2）}

\begin{tabular}{|c|c|c|c|c|}
\hline 暗 & & 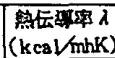 & 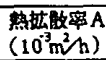 & $\begin{array}{c}\text { 日期授収率 } \\
a\end{array}$ \\
\hline 理配カルシウム & 9 & 0.040 & 1. 01 & 0.33 \\
\hline ソノトライト板 & 鳇水 & 0.60 & 0.68 & 65 \\
\hline 有孔无㳄アルミ板 (シリコン & 四证 & $=$ & - & 28 \\
\hline 督照料仕上げ，有れ时 & 俈水 & - & - & 0.37 \\
\hline
\end{tabular}

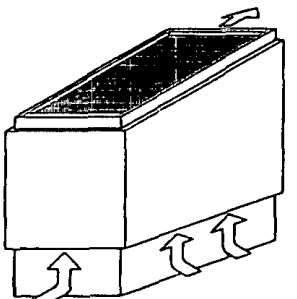

一体化仕像

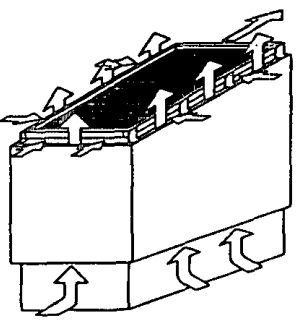

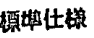

㘣一19 一体化仕様と標準仕様

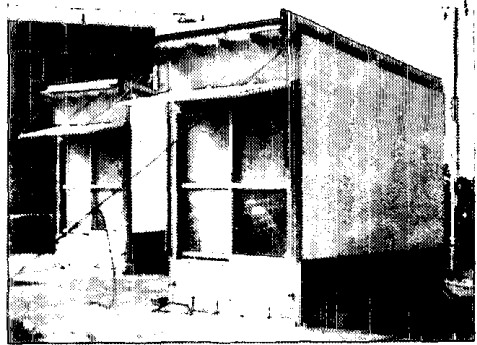

写项-2 試験家屋全景（実験 II）

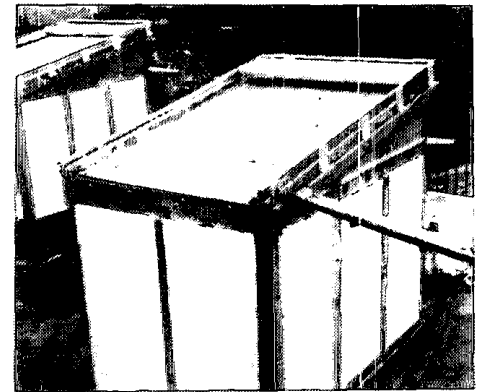

写真一3 試験家屋屋根面 
表一4 屋外比較実験内容（実験 II ）

\begin{tabular}{|c|c|c|c|c|c|c|c|c|}
\hline \multirow{3}{*}{ 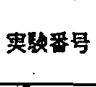 } & \multirow{3}{*}{$\begin{array}{c}\text { 实施月日 } \\
(1984 \text { 年 })\end{array}$} & \multirow{3}{*}{ 険尌項目 } & \multicolumn{3}{|c|}{ A增 } & \multicolumn{3}{|c|}{ B堁 } \\
\hline & & & \multirow[t]{2}{*}{ 断然材 } & \multicolumn{2}{|c|}{ 外披バネル } & \multirow[t]{2}{*}{ 断熟材 } & \multicolumn{2}{|c|}{ 外被パネル } \\
\hline & & & & 星根 & 重㨁朢 & & 星艮 & 重道壁 \\
\hline 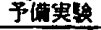 & $7 / 31.8 / 1$ & 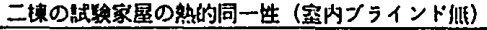 & 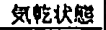 & 全闌 & 無 & 気陪状点 & & 每 \\
\hline II -1 & $\begin{array}{l}9 / 16.17 \\
9 / 22 \sim 24\end{array}$ & 遇択放射の效果 & \multirow{9}{*}{ 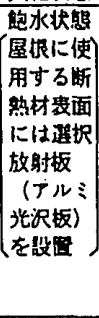 } & \multirow{3}{*}{ 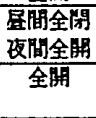 } & 有 & 配水状息 & 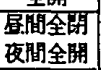 & 䈐 \\
\hline II-2 & $8 \longdiv { 4 . 5 }$ & 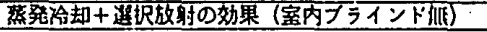 & & & \multirow[t]{3}{*}{ 無 } & \multirow[t]{7}{*}{ 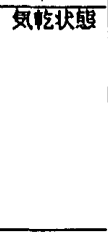 } & \multirow[t]{6}{*}{ 全闻 } & \multirow[t]{6}{*}{ JIII } \\
\hline II -3 & $8 / 6$ & 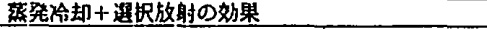 & & & & & & \\
\hline II-4 & $8 / 8,9$ & 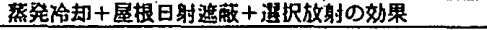 & & \multirow{6}{*}{$\begin{array}{l}\text { 居間全閏 } \\
\text { 改間全朋 }\end{array}$} & & & & \\
\hline II-5 & $8 / 15-17$ & 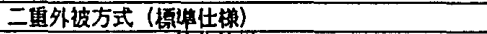 & & & \multirow[t]{2}{*}{ 有 } & & & \\
\hline II-6 & $8 / 11,12$ & 二重外被方式（一体化俚䖴） & & & & & & \\
\hline II -7 & $8 / 23,24$ & 二重外被方式（外被パネル表面は中間色） & & & 中間色 & & & \\
\hline II -8 & $8 / 27 \sim 29$ & 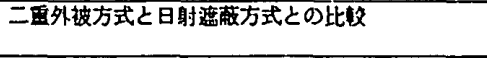 & & & & & 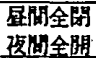 & 有 \\
\hline II -9 & $9 / 5,6$ & 二面外被方式と䔲発椧却方式との比忟 & & & & 欺水状熊 & 全明 & 烸 \\
\hline
\end{tabular}

表一5 室内空気温度の日平均值と変動幅

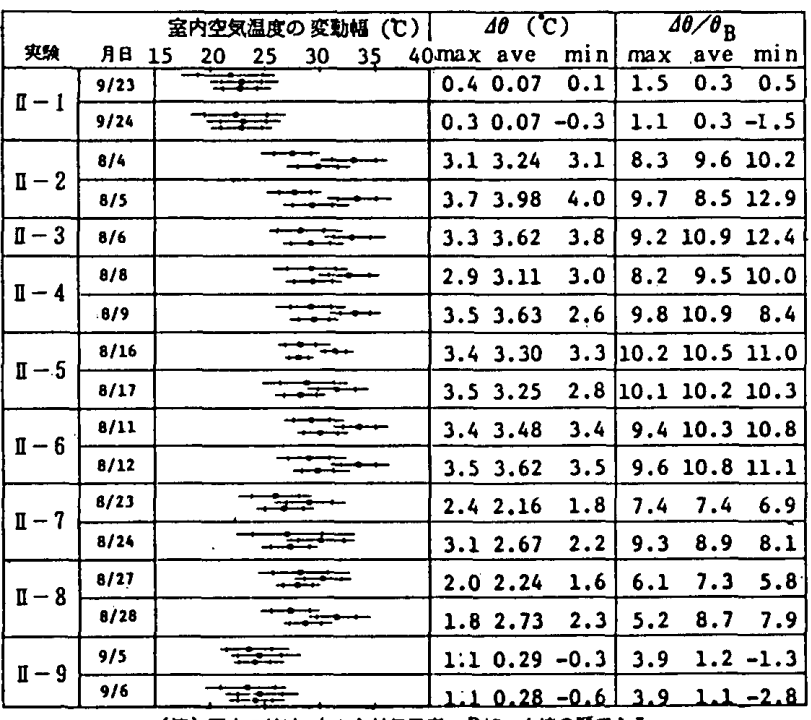

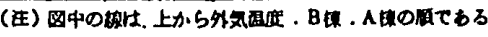
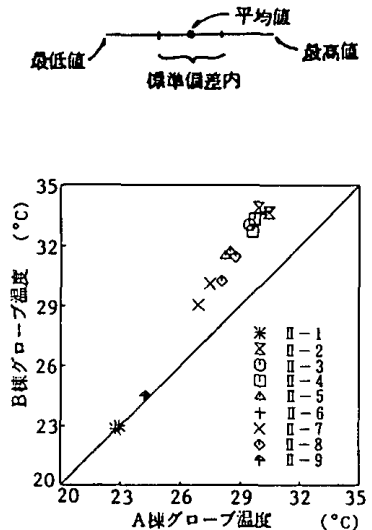

図一20 A 棟グローブ温度とB 棟グローブ温度の比較 (いずれも日平均値)

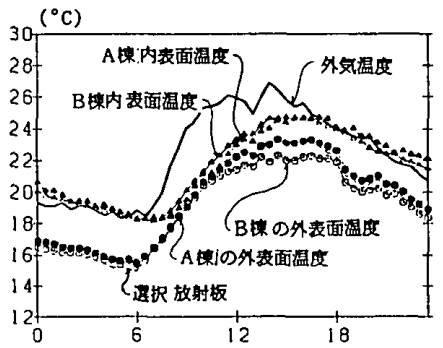

図一21 実験 II -1 の屋根表面温度（9月 24 日）
日平均値と変動幅，図一 20 には $\mathrm{A}$ 棟および $\mathrm{B}$ 棟の日平 均グローブ温度相互の関係を示す。また， A・B 二棟の 日平均グローブ温度をそれぞれ $\theta_{\mathrm{A}, \mathrm{ave}}, \theta_{\mathrm{B}, \mathrm{ave}}, ク$ グロブ

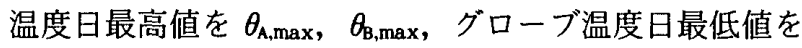
$\theta_{\mathrm{A}, \mathrm{min}}, \theta_{\mathrm{B}, \mathrm{min}}$, としたときの $\Delta \theta_{\mathrm{ave}}=\theta_{\mathrm{B}, \mathrm{ave}}-\theta_{\mathrm{A}, \mathrm{ave}}, \Delta \theta_{\max }$ $=\theta_{\mathrm{B}, \max }-\theta_{\mathrm{A}, \max }, \Delta \theta_{\min }=\theta_{\mathrm{B}, \min }-\theta_{\mathrm{A}, \min }$ を算出し, 表一 5 に示す。ただし，実験内容が同一であっても，暑い日， すなわち $\theta_{\mathrm{B}}$ が高い日には $\Delta \theta$ も大きくなる傾向がある ため(図一 20 参照)， $\Delta \theta$ を $\theta_{\mathrm{B}}$ で割って無次元化した $\Delta \theta_{\mathrm{ave}} / \theta_{\mathrm{B}, \mathrm{ave}}, \Delta \theta_{\max } / \theta_{\mathrm{B}, \max }, \Delta \theta_{\min } / \theta_{\mathrm{B}, \min }$ も防暑効果を表 す目安として示した。

実験 II -1 では，屋根面に施した選択放射板の効果を 検討するため，標準仕様の二重外被方式とした A・B 二棟のうち，A棟の屋根のゾノトライト板外表面に選択 放射板を設置し，二棟とも夜間だけ屋根ブラインドを全 開にした。図一 21 に実験 II - 1 の屋根表面温度を示す。 選択放射板表面温度は B 棟屋根の表面温度より最大 $0.5^{\circ} \mathrm{C}$ 低下しているものの, 夜間, $\mathrm{A} \cdot \mathrm{B}$ 二棟の屋根内 表面温度差はほとんど認められない。日中の屋根外表面 温度は $\mathrm{A}$ 棟の方が $\mathrm{B}$ 棟を最大で $2^{\circ} \mathrm{C}$ 程上回る。これは 選択放射板の有孔率が $31 \%$ と小さく蒸発が抑制される ためである。

実験 II -2〜7では，いずれも，A 棟の断熱材を飽水状 態に，B棟の断熱材を気乾状態に保ち $\mathrm{A}$ 棟の外被パネル の有無およびその仕様が自然室温変動に及ぼす影響につ いて検討する。表一5に示すように，垂直壁外被パネル の表面を中間色とした実験 II -7 の場合には A B 二 棟 のグローブ温度差 $\Delta \theta$ は $2 \sim 3^{\circ} \mathrm{C}$ 程度となるが，それ以 外はいずれも $\Delta \theta$ は $3 \sim 4^{\circ} \mathrm{C}$ となり，断熱材を飽水化す ることによる防暑効果は外被パネルの有無, 仕様に関係 なく明らかである。

図一22 - 25にはA 棟に外被パネルを設置せず従来の 蒸発冷却方式とした実験 II -3 の結果を，図一26〜29に はA 棟に外被パネルを設置し標準仕様の二重外被方式と した実験 II-5の結果を示す。なお，垂直壁外被パネル 表面は白色であり，屋根ブラインドは 6 時から 19 時ま で全閉，それ以外は全開とした。実験 II -3のA棟室内 


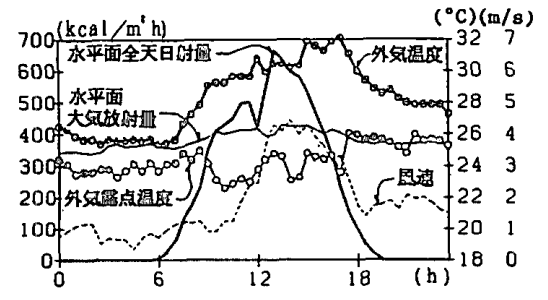

图一22 実験 II -3 の外界気象要素 (8月6日)

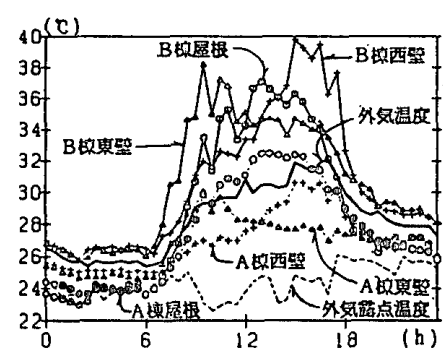

図-23 実験 II -3 の外表面温度

(8月6日)

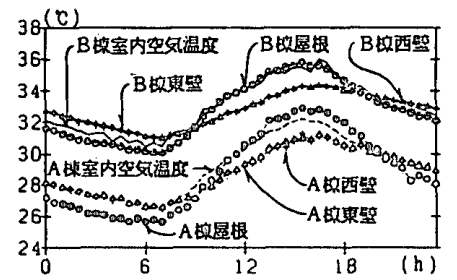

图一24 実験 II-3 の内表面温度

(8月6日)

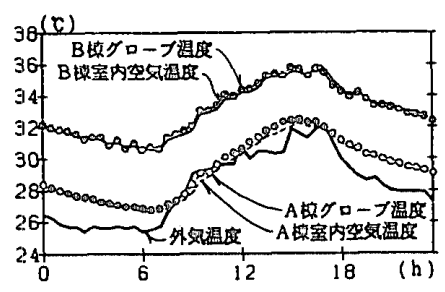

图一25 実験 II -3 の室内空気温度 およびグローブ温度 (8 月 6 日）

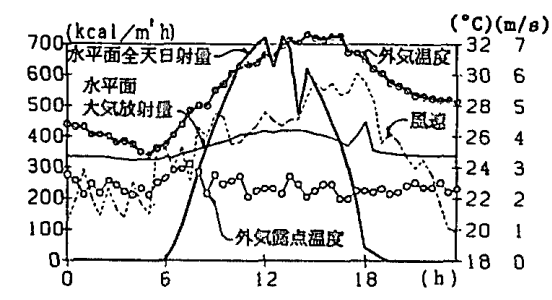

图一26 実験 II -5 の外界気象要素 (8月17日)

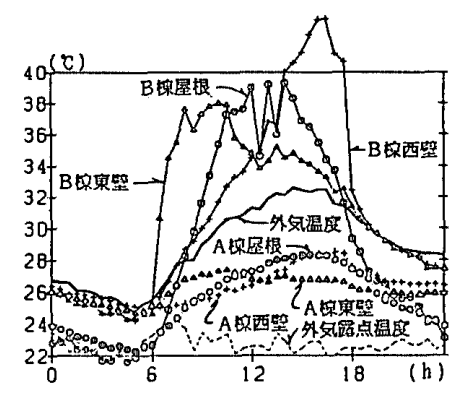

圆-27 実験 II -5 の外表面温度

(8月 17 日)

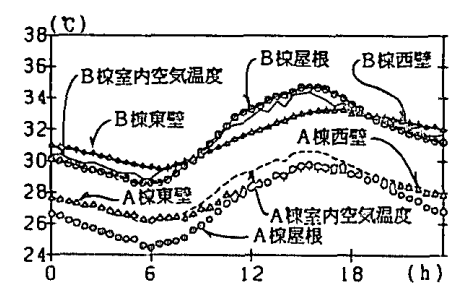

图一28 実験 II -5 の内表面温度 (8月17日)

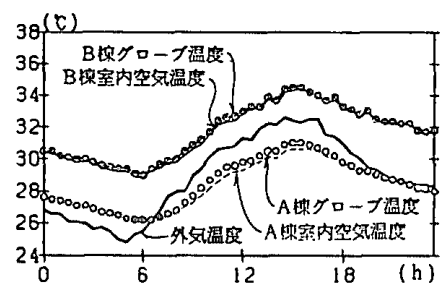

图一29 実験 II -5 の室内空気温度 およびグローブ温度 (8月 17 日）

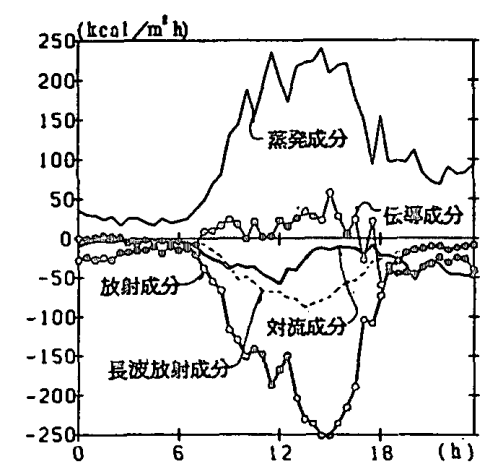

図一32 実験 II-3 のA棟西壁外表面の 成分別熱流（8月6日）

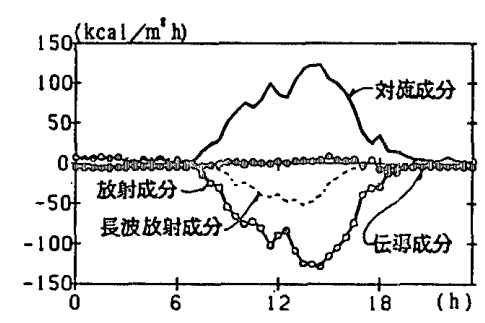

図一33実験 II -3 のB棟西壁外表面の 成分別熱流（8月6日）

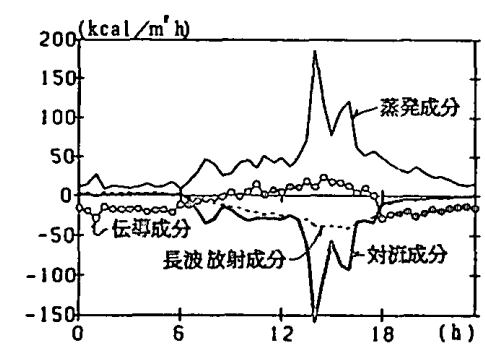

图一34 実験 II -5 のA棟西壁外表面の 成分別熱流 (8月 17 日)

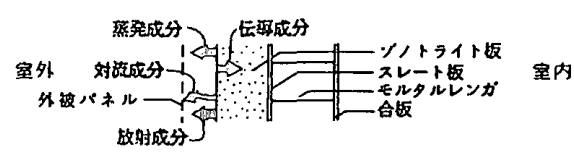

図一35 西壁外表面の熱収支

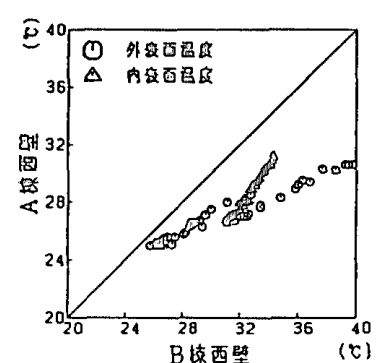

図一30 実験 II-3 の西壁内表 面温度および外表面 温度の $\mathrm{A}$ 棟と $\mathrm{B}$ 棟と の比較 (8月 6 日)

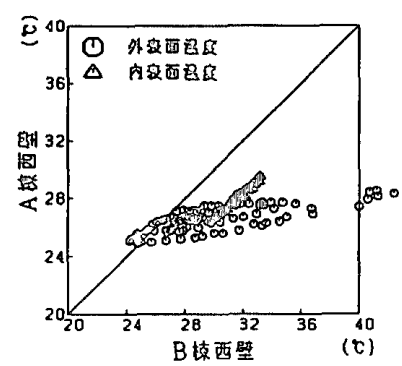

図一31 実験 II-5 の西壁内表 面温度および外表面 温度の $\mathrm{A}$ 楂と $\mathrm{B}$ 槙と の比較（8月17日）

空気温度およびグローブ温度は，8時－12 時に外気温度 と同程度となるが，日中ピーク時では外気温度を 0.5 $1.5^{\circ} \mathrm{C}$ 上回る。一方, 実験 II -5 の A 棟室内空気温度お

よびグローブ温度は外気温度より日平均で $0.6^{\circ} \mathrm{C}$, 日中 は $1.5 \sim 2{ }^{\circ} \mathrm{C}$ 低くなる。これは図一 27 に示すように $\mathrm{A}$ 輠 の断熱材外表面温度が東・西壁, 屋根ともに, 日中，外 気温度より最大 $4 \sim 5{ }^{\circ} \mathrm{C}$ 低くなるためである。また，実 験 II -5 の $\Delta \theta_{\max } / \theta_{\mathrm{B}, \max }$ は，実験 II -2〜7のうちで最も大 きくなる。図一 30,31 では実験 II -3 および実験 II -5 に おける $\mathrm{A}$ 棲と $\mathrm{B}$ 棟の西壁内外表面温度を比較している が，実験 II -5 のA 槙西壁外表面温度は日中でもほとん よ゙上昇せず， $\mathrm{B}$ 桓で $40^{\circ} \mathrm{C}$ を超えるときでも $28^{\circ} \mathrm{C}$ 程度 に抑えられる。図一 $32 ， 33$ は実験 II -3 におけるA棟よ B棟の，図一34 は実験 II -5における A 棟の西壁断熱材 外表面熱流計算值を成分別に表したものである。ただし， いずれの成分も図一 35 に示す方向を正とする。実験 II -3のA棟では断熱材を飽水化することにより日射吸収 
率が増大するため，外表面に入射する放射成分は B棟を 大きく上回るが，蒸発による放熱でそれを補っている。 実験 II -5 では外被パネルで日射が遮へいされるため入 射する放射成分は城少するが，蒸発量も実験 II -3に比 べて著しく減少している。これは，断熱材と外被パネル の間隔が $35 \mathrm{~mm}$ であり，十分な通気が得られなかった ためと思われる。

図一-36〜41には実験 II-6 と実験 II -7 の結果を示す。 実験 II -6ではA 棟を一体化仕様とした。この仕様は冬 季の雨仕舞には有利であるが, 通気層内の空気の移動が 少なくなるため, 図一 37 に示すように A 棟各部位の断 熱材外表面温度は外気温度より $1 \sim 2^{\circ} \mathrm{C}$ 下がる程度であ る。実験 I - 7 では通気による排熱を促進させるため標 準仕様としたA 棟垂直壁外被パネル外表面を日射吸収率 の大きな中間色とした。図一39に示すようにA棟の東・ 西壁断熱材外表面温度はピーク時に外気温度より1〜 $2{ }^{\circ} \mathrm{C}$ 高くなる。これは外被パネルの温度上昇により，断 熱材に入射する長波放射が増加し，通気層内空気からの 対流熱伝達量も增えたためだと思われる。

実験 II -8では，A 棟の断熱材を飽水状態，B棟の断 熱材を気乾状態に保ち,二棟とも外被パネルを設置した。 すなわち，A棟を二重外被方式，B棟を日射遮へい方式 とした場合である。実験結果を図一 42,43 に示すが， $\mathrm{A}$ 棟の室内空気温度およびグローブ温度は $\mathrm{B}$ 棟を下回 り，その差はB棟に外被パネルを設置しなかった実験 II -5 よりわずかに減少し，2 $23^{\circ} \mathrm{C}$ 程度である。本実験に おいて二棟の室温差は, 断熱材の含水状態の違いのみか ら生ずるものであり，二重外被方式における蒸発冷却の 効果を示している。

実験 II -9 では A 棟と B 棟の断熱材を飽水状態に保ち

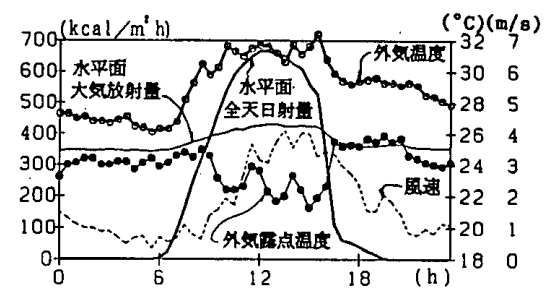

图一36 実験 II -6 の外界気象要素 (8月12日)

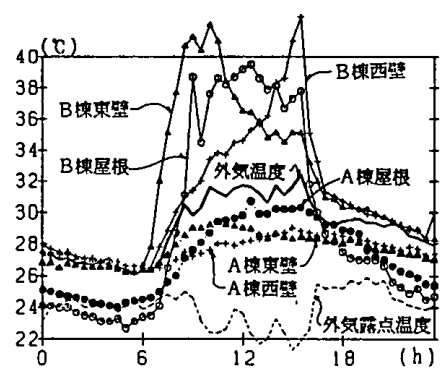

图一37 実験 II -6 の外表面温度 (8月12日)

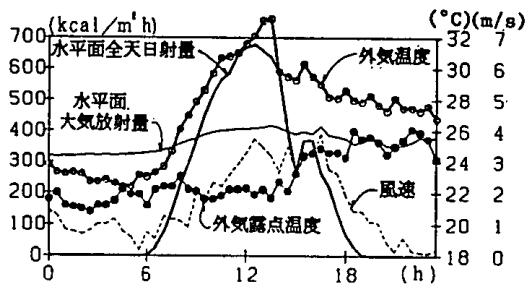

図一38 実験 II -7 の外界気象要素 (8月 24 日)

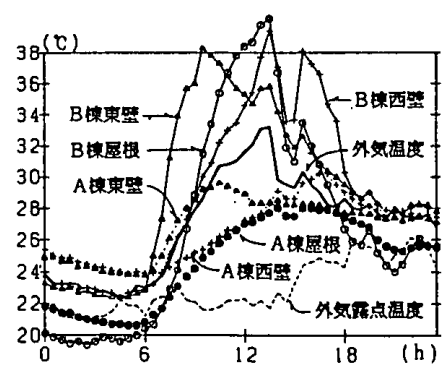

图一39 実験 II-7 の外表面温度 (8月24日)
$\mathrm{A}$ 棟のみに外被パネルを設置した。すなわち， $\mathrm{A}$ 棟を二 重外被方式，B棟を蒸発冷却方式とした場合である。実 験結果を図一 $44 ， 45$ に示す。 $A$ 棟の室内空気温度およ びグローブ温度は， $\mathrm{B}$ 棟より日中最大で $1.5^{\circ} \mathrm{C}$ 低く， 夜間は逆にB棟をわずかながら上回る。

一連の屋外比較実験について全体的な考察をするた め, 図一 46 に試験家屋日平均室内空気温度 $\bar{T}_{i}$ と日平均 外気温度 $\bar{T}_{0}$ との差 $\Delta \bar{T}=\bar{T}_{l}-\bar{T}_{0}$ と水平面全天日射量 日積算値との関係を示し, 図一 47 には $\Delta \bar{T}$ と日平均風 速との関係を, 図一 48 には $\Delta \bar{T}$ と外気の日平均絶対湿 度との関係を示す。空面の室内ブラインドを使用して断 熱材を飽水状態に保った実験 II -1 および実験 II-3～9 の $\mathrm{A}$ 棟と実験 II $-1,9$ の B 棟では $\Delta \bar{T}$ は $1.5^{\circ} \mathrm{C}$ 以下とな る。実験 II -1，5，8，9の A 棟之実験 II -1 の B 棟はいず れも二重外被方式（標準仕様）であるが $\Delta \bar{T}$ の值にか なりのばらつきがみられる。ただし，秋型の気象となっ た実験 II -1（9月 23 日，24日）および実験 II -9（9月 5 日，6日）と，風速が小さく外気の絶対湿度が大きい 8月 28 日を除けば，いずれも $\Delta \bar{T}$ は負の值となり，日 平均室内空気温度は日平均外気温度を下回る。

\section{4 冬季の断熱性能}

二重外被方式の冬季の断熱性能を検討するため, 1985 年冬季に, $\mathrm{A}$ 棟を二重外被方式; B棟を外断熱方式として 全日暖房奏験を行った。サーモスタット設定温度は $20^{\circ} \mathrm{C} \sim 24^{\circ} \mathrm{C}$ である。実験結果を図一 49,50 に示すが, 暖房用供給熱量日積算值は A 棟で $11290 \mathrm{kcal}$, B 棟で $11794 \mathrm{kcal}$ となる。このように二重外被方式とするこ とによりわずかではあるが冬季の断熱性能も向上する。

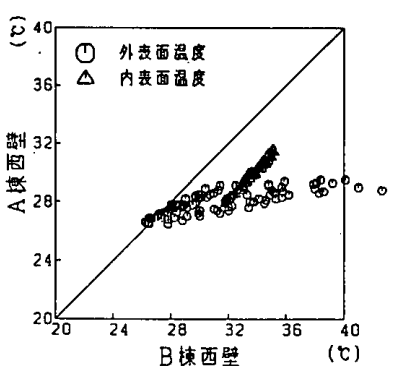

図一40 実験 II-6 の西壁内表面温度 および外表面温度のA 棟と $\mathrm{B}$ 棟との比較 (8月 12 日)

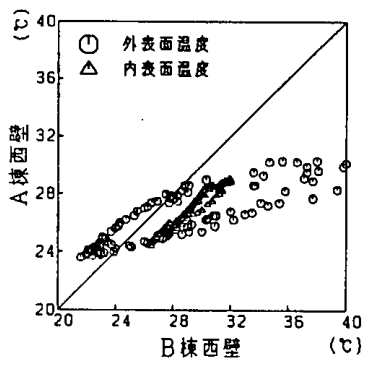

図一41実験 II-7 の西壁内表面温度 および外表面温度の A 棟と $\mathrm{B}$ 棟との比較（8月 24 日） 


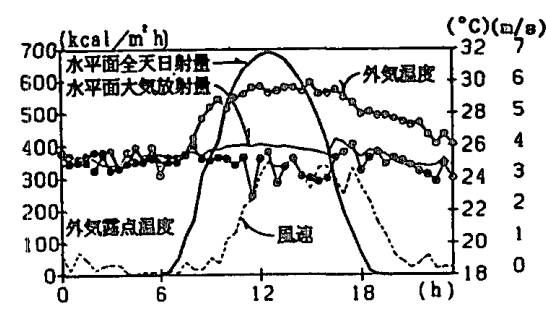

図一42 実験 II -8 の外界気象要素

(8月 28 日)

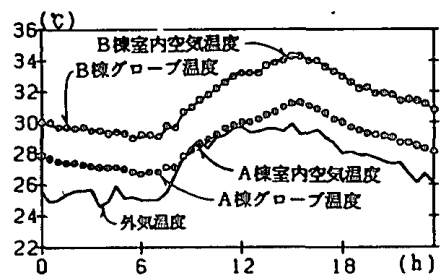

图一43 実験 II -8 の空内空気温度および グローブ温度（8月28日）

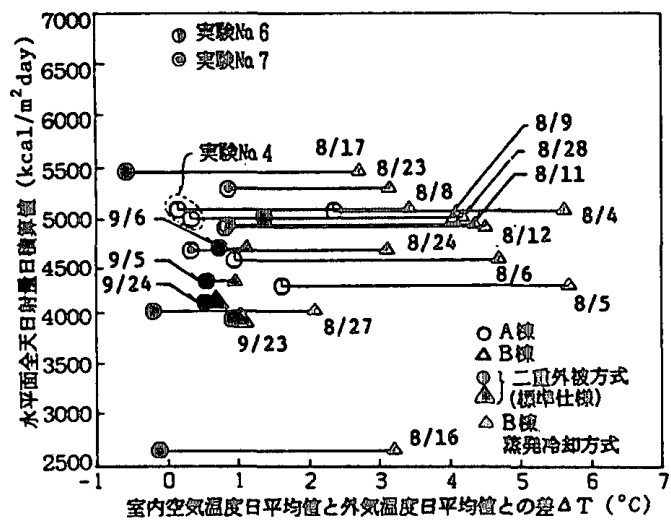

图一46 室内空気温度日平均值と外気温度日平均値との 差 $\Delta \bar{T}$ と水平面全天日射量日積算値との関係

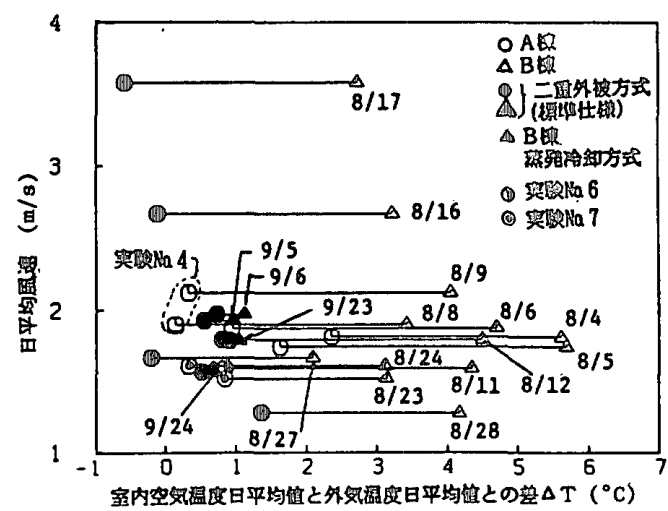

图一47室内空気温度日平均值と外気温度日平均値との 差 $\Delta \bar{T}$ と日平均風速との関係

4. 試験家屋を対象としたシミュレーションによる検討

4.1 計算プログラムおよび計算条件

外断熱, 蒸発冷却, 二重外被方式が室温変動に及ぼす 影響をシミュレーションにより検討する。シミュレー ショコには，筆者らが開発した室内変動解析プログラ ム・PSSPを用いた。本プログラムにおいて，壁体内 表面の熱収支式および室内空気の熱収支式は逐次状態遷

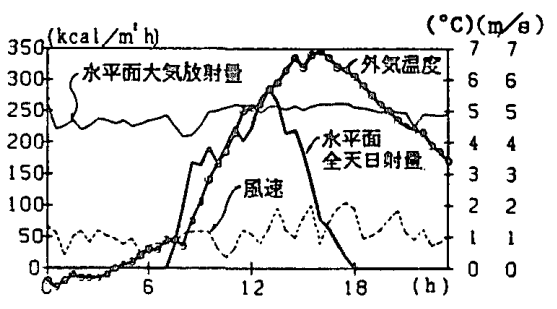

图一49 全日本暖房実験の外界気象要素 (2月 25 日)

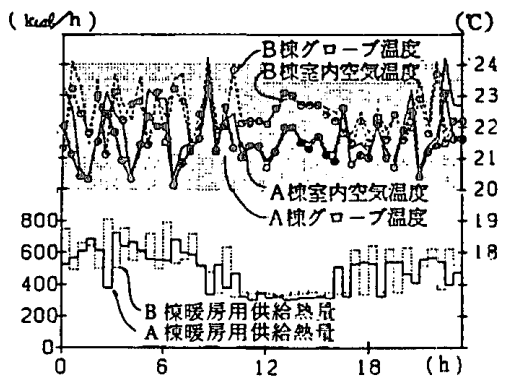

図一50 全日暖房実験の実験結果 (2月 25 日)

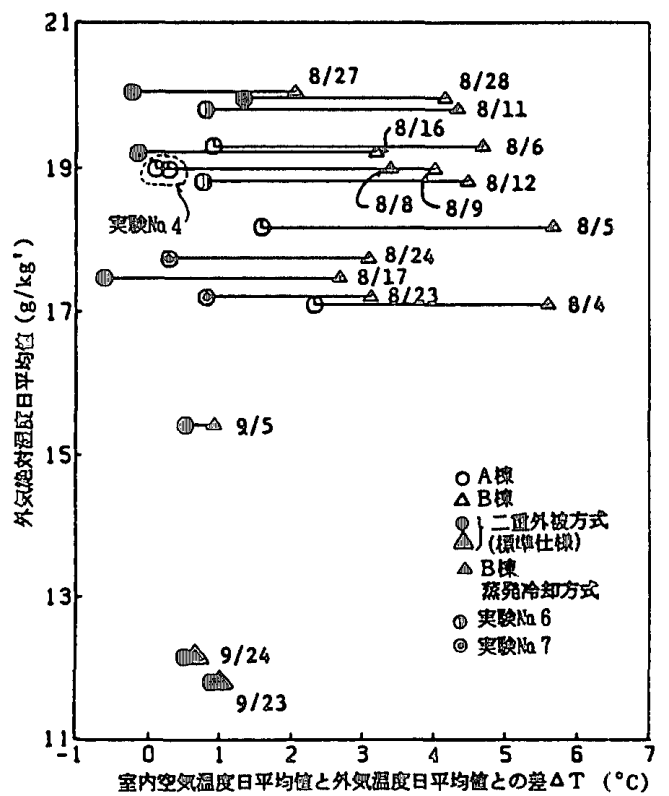

关一48 室内空気温度日平均値と外気温度日平均徂との 差 $\Delta \bar{T}$ と外気絶対湿度日平均値との関係

移の概念に基づくものであり，日照面の移動を含む室内 相互放射伝熱も詳細に考慮できる。また，壁体が飽水状態 にある場合，その表面からの水分蒸発量はルイスの関係 式に従うものとして算定し，壁体内部の水分移動に伴う 熱移動は，等価な熱伝導率，熱拡散率を与えて近似的に 取り扱う。計算条件は下記のごとく設定した。

1）実験 IIに用いた試験家屋を計算対象とした。武験 家屋の壁体は図一18 に示すように 14 に分割し，庇の影 響も考虑する。断熱材の熱定数は表一3に示す值を，そ の他の部材は文献 4）に示す值を使用する。長波放射率 はすぺての部位で 0.95 を仮定した。

2）外壁外表面における対流熱伝達率は, 外界の風速 
と風向から壁面近傍風速を推定し，その関数として与え $る^{5)}$ 。

3）室内表面の対流熱伝達率は一時刻前の壁体表面温 度と室内空気温度との差の関数として与える ${ }^{5)}$ 。

4）屋根と壁の日射遮へいを行う場合には, 日射吸収 率 0.3 で熱抵抗の無視できる可動式の外被パネルを考 え，パネルと壁面の長波放射熱授受を考慮する。また， 外壁外表面と外被パネル内外表面の対流熱伝達率は，壁 面近傍風速より求める5!。昼間のみ日射遮へいを行う場 合は, 19 時から翌朝 6 時まで外被パネルを取り除き, 夜間の大気放射冷却を利用する。

5）表面処理した断熱材を使用する場合，その表面か らの蒸発量は,ルイスの関係から求められる飽水層表面 の蒸発量に前述の蒸発比を乗じて算出する。

6）換気を行う場合には機械換気を想定し，外気温度 が室内空気温度より低いときファンを運転する。換気回 数は 10 回 $/ \mathrm{h}$ とする。

7）室内ブラインドは使用しない。

8）計算出力日は 1984 年 8 月 5 日とし, 熱伝導によ る壁体表面熱流の状態量に対して 30 日間の繰返し計算 を行った後, 8 月 2 日から外界気象デー夕を入力した。

4.2 シミュレーション結果
8 月 5 日（実験 II -2）の実験值と，これに対応する計 算值を図一 51 ～54 に示す。選択放射板を付けた A 棟屋 根のゾノトライト板は灰色体とみなし，その長波放射率 は 0.95 とした。日射吸収率は 0.37 ，蒸発比は 0.57 で ある。A棟と B 棟の屋根内表面温度計算值は実測値より も若干高い值を示すが，その他の各内外表面温度と室内 空気温度の計算值は $\mathrm{A}$ 棟，B棟いずれも実測値を良く補 足している。

図一55には，（1）試験家屋の断熱材を気乾状態に保 つ外断熱方式，（2）外断熱壁体の外側に外被パネルを 設置する日射遮へい方式，（3）断熱材を飽水状態に保 つ蒸発冷却方式，（4）蒸発冷却方式の断熱材を通気防 水シートで覆った場合，（5）蒸発冷却と日射遮へいを 併用した二重外被方式，以上 5 通りの室内空気温度シ ミュレーション值を示す。日射遮へい方式の室内空気温 度は外断熱方式より日中約 $1^{\circ} \mathrm{C}$ 低下するだけであるが, 蒸発冷却方式の室内空気温度の低下は著しく, 外断熱方 式より約 $4^{\circ} \mathrm{C}$ 低くなる。断熱材に表面処理をした場合 も，しない場合と同様の防暑効果がある。二重外被とし た場合，室内空気温度は蒸発冷却方式より日中約 $1^{\circ} \mathrm{C}$ 低下する。

また，二重外被方式とした試験家屋において，さらに
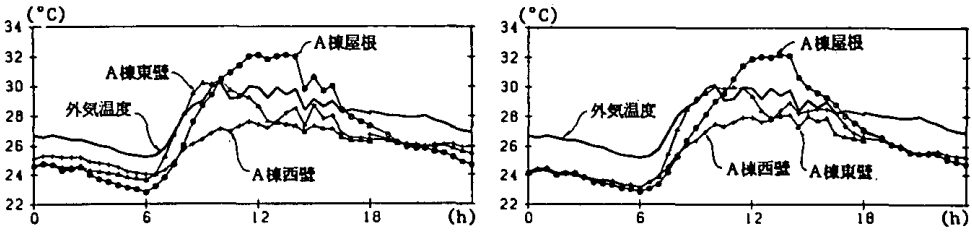

図一51 A 棟外表面温度の実測値（左）と計算値（右）
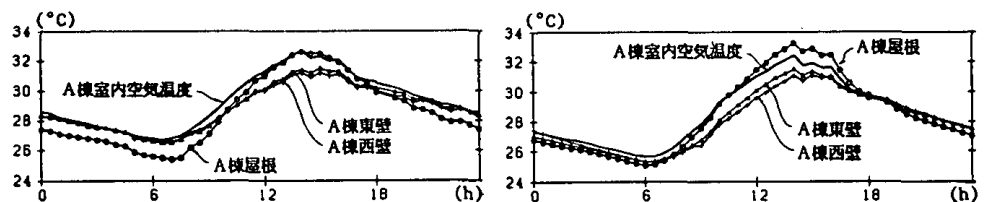

図一52A 棟室内空気温度および内表面温度の実測値 (左) と計算値 (右)
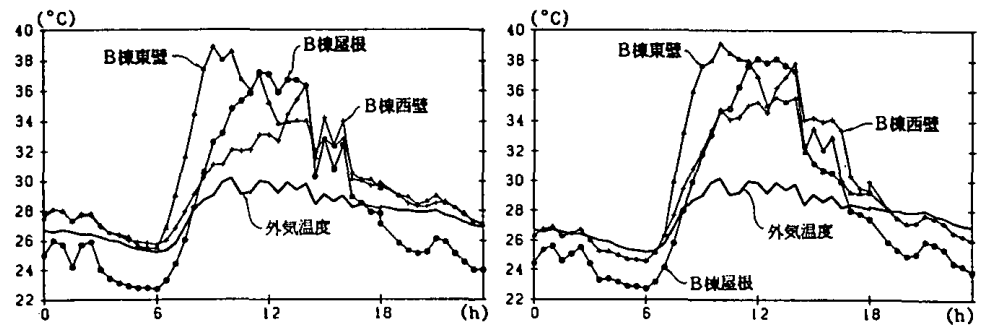

図一53 B 棟外表面温度の実測値（左）之計算値（右）
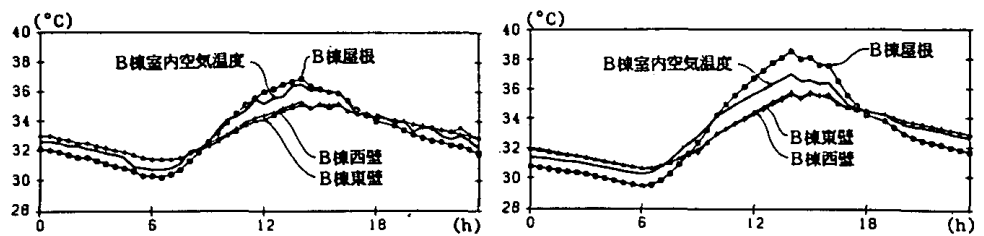

図一54 B 棟室内空気温度および内表面温度の実測値（左）と計算値（右）

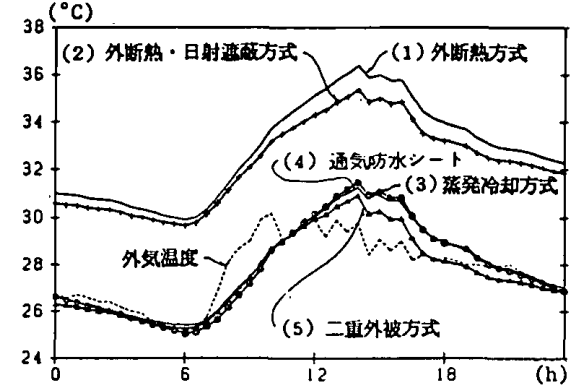

图一55 シミュレーションによる室内空気温度 (その 1)

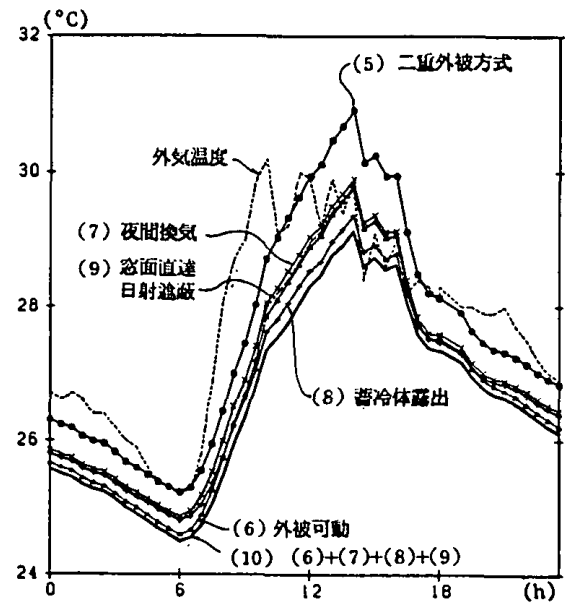

図一-56 シミュレーションによる室内空気温度 (その 2) 
（6）外被パネルを可動とし夜間開放する場合，（7） 夜間換気を併用する場合，（8）壁体内表面の合板を撤 去し蓄冷体であるモルタル・レンガを露出させる場合，

（9）空面外側で直達日射を遮へいする場合，(10）上記 の（6）（7）（8）（9）の手法および仕様をすべて取 り入れる場合を想定し，そのシミュレーション結果を図 一-56に示す。外被パネルを可動として夜間放射冷却を 利用する場合, 室内空気温度は（5）上り夜間 $0.7^{\circ} \mathrm{C}$ 低下し，この効果は日中まで維持される。また，夜間換 気との併用あるいは空面直達日射の遮へいにより室内空 気温度は（5）より夜間 $0.4^{\circ} \mathrm{C}$, 日中 $1^{\circ} \mathrm{C}$ 弱低下する。 蓄冷体であるモルタル・レンガを室内表面に露出させた 場合, 日中の室温低下は著しく（4）より最大で $1.5^{\circ} \mathrm{C}$ 低下する。

\section{5. 結 論}

蒸発冷却の利用による外断熱壁体の夏季熱性能改善を 目的として, 冬季の断熱性能も確保できる高性能外断熱 壁体を提案し，二棟の試験家屋を用いた屋外比較実験お よびシミュレーションにより，その有効性を検討した。 主な結果は以下のとおりである。

（1）蒸発冷却方式は，全外壁に対する蒸発壁の面積 上が $50 \%$ 程度あれば，通常の断熱構法に比べて試験家 屋の日中の室温を $2 \sim 4^{\circ} \mathrm{C}$ 程低下させることができる。

（2）冬季の断熱性能確保のため, 白色通気防水シー 卜や白色撥水剤で断熱材の表面処理を行う場合，断熱材 表面からの蒸発量は娍少するが，表面の日射吸収率は小 さくなり, 表面処理のない場合と同じ程度の防暑効果を 示す。

（3）夜間の放射冷却を利用するため屋根蒸発面に有 孔選択放射板を設置する場合，選択放射板の表面温度は 多少低下するものの室内への影響は小さく，かえって日 中の蒸発冷却を抑制することになる。
（4）二重外被方式を採用することにより，日中，試 験家屋の自然室温を外気温度以下にまで下げることが可 能であるが，通気層の間隔や形状は蒸発性能を左右する と考えられるので，今後さらに詳しく検討する必要があ る。

（5）二重外被方式の防暑効果は屋根の外被パネルを 可動にして大気放射冷却を利用することや蓄冷体を室内 表面に露出させることによりさらに増大する。

（6）冬季に行った全日暖房奏験の結果，二重外被方 式は従来の外断熱方式と比べて若干ではあるが断熱性能 も向上する。

本研究の一部は, 昭和 $58 \cdot 59$ 年度文部省科学研究費 補助金エネルギー特別研究・自然エネルギーの研究・ 太陽エネルギー利用の研究（課題番号：58040039・ 59040039 , 研究代表者: 国友孟) - 分担課題「選択放射 と水分蒸発による冷却効果を利用した外断熱壁体の高性 能化」によるものである。

\section{参考立献}

1) 木村建一, ほか: 蒸発冷却屋根の研究, 日本建築学会大 会学術講演梗概集, 1984

2）石川幸雄：屋根散水を考虑した自然空調に関する研究, 日本建築学会大会学術講演梗概集，1982

3）松本 衛, ほか：雨を利用した吸水性屋根面の蒸発冷却 効果に関する研究, 日本建築学会大会学術講演梗概集, 1984

4）龍 有二, ほか：外表面飽水層を有する外壁パッシブ・ クーリング方式の熱的性能, 日本建築学会建築環境工学 論文集，第 5 号，1983

5）龍 有二，ほか：蒸発冷却を利用した外断熱家屋の夏季 自然室温変動解析, 九州大学工学集報 Vol. 58, No.2, 1985

6）植田賢一，ほか：模擬太陽実験装置による断熱・蒸発性 能試験, 日本建築学会九州支部研究報告, 第 28 号, 1985 


\section{SYNOPSIS}

UDC : 697.13

\section{IMPROVEMENT IN THERMAL PERFORMANCE OF OUTER INSULATED WALL USING EVAPORATIVE COOLING}

by Dr. YOShimi URANO, Prof. of Kyushu Univ., Dr. TOSHIYUKI WATANABE, Assoc. Prof, of Kyushu Univ., Dr. TETSUO HAYASHI, Research Assist. of Kyushu Univ, and YUJI RYU, Graduate Student of Kyushu Univ., Members of A.I. J.

Thermal insulation of exterior walls is effective to reduce heating energy requirement, but in summer it occasionally brings an increase of cooling load and keeps room temperatures at a high level without air-conditioning. In this case, the utilization of water evaporative cooling by wetting thermal insulation materials laid on outside surface is considered to be one of the passive cooling methods.

The authors carried out two series of field experiments with twin test houses and simulations for these houses, to improve thermal performance of outer insulated walls by using evaporative cooling.

1) Evaporative cooling effects of the outside insulation system whose insulation materials were saturated with water were examined using the twin test houses. Surface treatments of the insulation material were considered to keep insulation materials air-dried in winter.

2) After the houses were reconstructed, we examined thermal effects of the double envelope system, which had panels for solar shading at outside surfaces of the evaporative cooling system. Panels of the roof were movable and could be opened at night to use atomospheric radiation cooling.

3) Simulations for these houses were made by using the calculation program PSSP proposed by the authors.

The results showed that the outgoing heat flow through exterior walls in the evaporative cooling system increased by reason that the outside surface temperatures lowered and thermal resistance of the insulation materials decreased. Furthermore this phenomenon was promoted in the double envelop system because outside surface temperatures lowered near by the wet-bulb temperature of ambient air. 